\title{
LGBTQ Equal Employment v. Religious Liberty Objections What Employers Should Accommodate
}

\author{
Michael T. Zugelder \\ Old Dominion University
}

\begin{abstract}
The Supreme Court's decision in Bostock v Clayton County Georgia, (2020), held that America's LGBTQ employees are within the protection of Title VII of the Civil Rights Act of 1964. However, there have been concerns that inclusion may burden religious liberties. Firm wide religious objection to equal employment of $L G B T Q$ employees rest on very narrow grounds. When employees make religious objections, employers should be flexible, tolerant, and use good judgement in deciding whether and to what degree to accommodate them. Employers must protect equal employment opportunities and should strive to create a culture of inclusion and respect.
\end{abstract}

Keywords: $L G B T Q$, discrimination, religion, accommodation

\section{INTRODUCTION}

To the surprise of many, the US Supreme Court held that LGBTQ employees are protected from sex discrimination by Title VII of the Civil Rights Act. The Court's decision, by a 6 to 3 vote, resolved discrimination claims of LGBTQ employees in three appellate cases consolidated from several divided Federal Circuits. The 33-page majority opinion in Bostock v. Clayton County Ga. (2020) stands in direct opposition to an administration that had recently nominated its unlikely author, conservative Justice Gorsuch, one of three conservatives added to the Court during the Trump administration. The decision sets a new civil rights landmark that over four decades of legislative attempts in Congress and eight years of executive orders and Equal Opportunity Employment Commission (EEOC) guidance's issued during the two-term Obama administration (cites) could not establish. Now, LGBTQ employees of both public and private employers are protected from sex discrimination to the full extent of the statute. Presumably that includes protection from all forms of job discrimination based on sex. The decision is another significant step in the Court's recognition of equal rights for LGBTQ individuals.

While Bostock alerts employers that LGBTQ employees are now protected by Title VII's prohibition against sex discrimination, questions remain whether and to what degree Title VII's nondiscrimination mandate will impose affirmative employer duties to accommodate transgender LGBTQ employees. Moreover, Bostock left a serious issue unresolved that has the potential to pose future limitations to title VII protections of equal LGBTQ employment rights: Objections based upon discrimination against the free exercise of religion and religious liberties.

This article will consider the complex challenges posed by Title VII protection of LGBTQ employees and concerns for the religious freedom that may conflict with that protection. In part I, an overview of the law up to Bostock and procedural history of the three appellate cases that lead to its holding will be 
reviewed. In Part II the several legal grounds discussed by the Bostock Court for the possible assertion of employers' religious based objections to LGBTQ employment rights will be considered. In part III, the current status of employers' obligations toward both groups, LGBTQ employees and employees with religious based objections, in light of Bostock_will be discussed. Part IV will propose employer policies and procedures that support a balanced inclusive approach. Finally, part V will offer concluding remarks toward a workplace culture of respect.

\section{LGBTQ EQUAL EMPLOYMENT}

Title VII of the Federal Civil Rights Act of 1964 prohibits discrimination because of an "individual's... sex" (42 USC 2000e et sec) The section of the law at issue in Bostock applies to private sector employers of 15 or more employees, state and local governments, employment agencies, and labor unions. (2000e2a1) The decision has a major impact on Federal employment protection for LGBTQ employees. For over 40 years, Congress has been unable to amend Title VII to expressly include LGBTQ employees, or adopt separate remedial legislation, with its most recent attempt again stalled in the House. (Equality Act, 2019).

While the Court had decided that the Constitution protected LGBTQ couples right to marry in Obergefell $v$. Hodges, (2015), there still was no nationwide protection for LGBTQ employment rights. It seemed to be a next logical step for the Court, to decide whether Congress had intended to grant those rights when it originally passed Title VII. The Court said it had. By doing so, Bostock represents the Court's second major statement of support for the rights of LGBTQ individuals.

\section{Bostock Appeal and Holding}

The Bostock v. Clayton County, Georgia, (2020) decision was the result of three consolidated cases appealed from Circuits Courts split on the issue of whether LGBTQ employment rights were protected by Title VII. In each case the employer had terminated the employee for being either gay or transgender. In Bostock, a child welfare services coordinator for the county was fired for unbecoming conduct after he participated in a gay softball league. The Eleventh Circuit held that Bostock's claim of discrimination could not be made under Title VII. However, in Zarda v Altitude Express (2018) the Second Circuit ruled that a gay skydiving instructor who was fired after a customer complained to the employer could proceed with suit under Title VII. Along with these cases was a third where the Sixth Circuit had decided that suit under Title VII could proceed by a funeral director who alleged she was fired for being transgender in R.G.\&G.R. Harris Funeral Homes Inc. v EEOC, (2018) The employer in Harris had defended the discriminatory firing on the basis of its religious liberty, under the First Amendment guarantee of freedom of religion and the Religious Freedom Restoration Act (RFRA), (1993), an argument upheld by the trial court, but rejected on appeal by the Sixth Circuit were not reiterated by the employer when the case reached the Supreme Court. By giving the statutory term "sex" in the text of Title VII its ordinary meaning, the Court held that firing employees merely for their sexual orientation or transgender status was included within Congress' original prohibition against sex discrimination stating ) that "...[D]iscrimination based on homosexuality or transgender status necessarily entails discrimination based on sex: the first cannot happen without the second" (Bostock, p.1747) and that such discrimination " "has always been prohibited by Title VII's plain terms" so "that should be the end of the analysis". (Bostock, p.1743). However, Justice Gorsuch also noted employers with religious liberty objections to LGBTQ equal employment rights might raise them in future cases based on a variety of grounds. Those grounds are next considered.

\section{EMPLOYERS' RELIGIOUS GROUNDS TO AVOID EQUAL LGBTQ EMPLOYMENT RIGHTS}

Under Title VII, an employer cannot use their religious views to discriminate against employees of a protected class, which after Bostock now include LGBTQ employees. While not formally raised as a defense in the appeals, Justice Gorsuch noted that complying with Title VII's equal treatment of LGBTQ employees could require some employers to violate their religious convictions and threaten their free 
exercise. Noting the historic interest that Congress and the Court have had to balance equal employment rights under Title VII with religious liberties, the Justice made reference to several possible grounds the Court may in future cases consider to excuse enforcement of equal LGBTQ employment rights.

\section{Religious Organizations Exemption}

In recognition of the right to free exercise of religion guaranteed by the First Amendment to the Constitution, Congress provided a statutory exemption for "religious organizations" in the text of Title VII. (Civil Rights Act, 1964). The exemption is only available to religious based non-profits and not applicable to private firms even if firm owners have religious objections. In addition, the right to discriminate in employment is limited to preferential treatment-based employee religion affiliation. No other protected basis is allowed. So as an example, a Catholic Church or affiliated school could prefer to hire only employees of Catholic faith, even including its accountants or custodians, but could not refuse to hire them on another prohibited ground such as their race or sex (which now would include LGBTQ.) (Kasai, 2020)

\section{Ministerial Exception}

Through the Supreme Court's interpretation of the Free Exercise Clause of the Constitution's First Amendment, religious organizations are exempted from all forms of employment discrimination claims and suits brought by their "ministerial" employees- those with core religious functions, such as a minister, rabbi, or religious teacher. (Hosanna-Tabor v EEOC, 2012). The exception does not apply to non-core employees such as an accountant or custodian. But if it applies the impact is draconian. The Court has approved dismissal of claims of ministerial employees for age, disability, and sex discrimination (which now would include LGBTQ), (Mulvaney, 2020) and race discrimination- a result that has drawn recent harsh criticism. (Griffin, 2020)

\section{For Profit Firm Objections based on Religious Liberties}

Much more recently and less clear is the right of private sector firms to object to application of law based on the owner's strong religious beliefs. Cases asserting this ground for exemption from Title VII's equal treatment mandate have relied on First Amendment grounds, in conjunction with the Restoration of Religious Freedom Act (1993). The RFRA was passed by Congress to protect minority religious beliefs and practices from federal interference and in direct response to the Court's decision in Employment Division, Department of Human Resources of Oregon v Smith (1990) upholding denial of state benefits to native Americans, for their use of peyote in religious practices. Similar laws have been adopted by a number of states, (Brown \& Scott, 2019) and the RFRA has been used as a basis for executive orders of the Trump administration, all for the stated purpose of protecting religious liberty rights, but with the unfortunate effect of authorizing or reauthorizing discrimination against equal rights for LGBTQ individuals with respect to military service, certain public employment, housing, and public facilities and accommodations. (Simmons-Duffin, 2020).

The Court's first application of the RFRA to a for profit private sector employers came in Burwell v Hobby Lobby (2014) which held that the owners of a closely held firm could object to payment for contraceptives for its employees required by the Affordable Care Act (cite), because they strongly opposed abortion on religious liberty grounds. Subsequently, the Court approved the Trump administration's exclusion for other organizations including for profit employers. (Little Sisters of the Poor v Pa., 2020)

Another recent decision of the Court used the same religious liberty rationale, reversed a state court order that had directed a bakery owner who objected to gay marriage to make a wedding cake for same sex customers. (Masterpiece Cakeshop v Colo., 2018). More recently, religious liberty arguments were raised by a Catholic church affiliated foster care referral service that refused to license same sex couples to be foster parents. In Fulton $v$ City of Philadelphia (2019) the Third Circuit rejected the argument and approved the City's termination of its contract with the service. The case is on appeal before the Court and its decision is pending. While these cases may demonstrate the Court's broadening view of religious liberty rights, none of them involve LGBTQ employees or their employment rights under Title VII 
The case from the highest court to squarely address the issue on whether an employer can justify discrimination against an LGBTQ employee on religious grounds of the RFRA remains the Sixth Circuit decision in EEOC v. R.G.\&G.R. Harris Funeral Homes Inc._(2018), which was consolidated and affirmed in Bostock. The Harris case was brought to trial by the EEOC on behalf of its transgender funeral director, terminated because of her sexual identity by her private for-profit employer. The employer denied liability on several grounds- one that transgender status is not protected by Title VII, (a defense now nullified by Bostock), and on religious grounds based on the First Amendment, the RFRA and the Court's decision in Burwell v Hobby Lobby (2014). The Sixth Circuit applied the 3-part analysis established by the statute for a claim or defense under RFRA, concluding the statue did not apply to excuse the employer's sex discrimination against the transgender employee. First, it found that complying with Title VII prescriptions against sex discrimination did not substantially burden the employer's operation of its funeral homes. In particular, it held that a business could not rely on the bias or preference of its customers to establish such burden. Second, even if the employer's religious liberty had been found unduly burdened, the government, in this case the EEOC, had a compelling interest in the enforcement in Title VII's proscription against sex discrimination in employment. Finally, the court held that there was no less restrictive means to achieving the government's compelling interest of nondiscrimination in employment, other than by full enforcement of Title VII. While the employer in Harris did not reiterate the religious objection when the case reached the Supreme Court, the case is persuasive authority for the position that RFRA and religious objections do not supersede the equal employment rights of LGBTQ employees.

The Sixth Circuit's holding in Harris denied the employer's right to discriminate based on sex, and is consistent with Justices Alito's admonition (Burwell v Hobby Lobby, p. 733), that the religious liberty rights of the employer not be used to justify race discrimination. Legal commentators since Harris have also argued with good reason that an employer's enforcement of faith neutral nondiscrimination policies and work rules that includes LGBTQ employees required by Title VII, lacks direct government action targeting a specific religious belief seen in Hobby Lobby and subsequent cases, to allow those decisions to serve as a persuasive legal basis for private sector employers to refuse LGBTQ equal employment rights. (Brown $\&$ Scott, 2019).

\section{EMPLOYER TITLE VII OBLIGATIONS TO LGBTQ AND RELIGIOUS EMPLOYEES}

Employers will have the challenge of fashioning policies and procedures that comply with Title VII's newly found nondiscrimination mandate toward LGBTQ employees, while also accommodating LGBTQ employees and the religious convictions of employees in the workplace. A conflict arising between newly protected LGBTQ workers and coworkers opposed to them for religious reasons could well leave an employer in uncharted territory and potentially caught between two groups of protected employees, one LGBTQ and the other one faith based, with the possibility of each asserting discrimination claims. However, there are established rules of accommodation for employers to follow in order to avoid legal exposure.

\section{LGBTQ Nondiscrimination and Accommodations}

The Supreme Court's mandate of nondiscrimination in Bostock did not address several issues employers have to consider regarding LGBTQ employees, and in particular, transgender employees. However, these issues have already been addressed in the affirmative by EEOC decisions and guidance's, requiring nondiscrimination in health coverage for same sex couples, and accommodations in the form of identity consistent bathroom access, added medical leave and coverage, and dress code variances. (Ecker, 2018) An increasing number of states and localities have established nondiscrimination law that includes these accommodations. Federal agency directives including those of the Occupational Safety and Health Administration (OSHA, 2016) and the Office of Personnel Management (OPM, 2016) likewise require employers to provided transgender employees bathroom room access consistent with their identity.

Bostock has been persuasive beyond employment cases. Taking note of the decision under Title VII, the Fourth Circuit held that public schools must provide transgender students with identity consistent 
bathrooms under Title IX. (Grimm v Gloucester County Sc. Bd., 2020). New announcements from the courts and administrative agencies at all levels of government that require employers to act without discrimination and provide reasonable accommodation should be expected. As a practical matter, the overwhelming majority of Fortune 500 firms already have well established policies of accommodations for LGBTQ employees. (HRC, 2020) It would be the better practice to follow their lead.

\section{Religious Nondiscrimination and Accommodations}

Although not an issue in Bostock ${ }_{2}$ a question with the potential for more pervasive application and employer concern remains whether and to what degree religious liberty objections to equal LGBTQ employee rights could be raised not by employers, but by co-workers and supervisors and other employees opposed to LGBTQ employment rights, and if so, how employers should handle those, including whether there are any duties to accommodate such opposition.

It is settled law under Title VII that the employer with 15 or more employees must be neutral toward employees' religion and not discriminate against them because of their religious affiliation, practices or beliefs. In addition, employers have a duty to accommodate religious views and practices in conflict with employer's workplace rules and policies. The accommodation duty does not begin until the employee makes a request and only extends to the point of employers' "undue hardship", which the courts have determined to mean anything more than de minimis additional cost or inconvenience to the employer's operation. (TWA v Hardison) (1977). Examples or reasonable accommodations include granting requests for shift swaps, department transfers, leave modifications, and waivers from dress codes and training programs. State and local laws reaching smaller employers have similar requirements. (EEOC, 2014)

Several courts have addressed the employer's duty to accommodate when faced with an employee's religious objection to policies of diversity, equity, and inclusion that protect LGBTQ employment rights. A leading authority from the Ninth Circuit Court is Peterson v Hewlett-Packard (2004). Peterson described himself as a devout Christian who viewed homosexuality as a violation of scripture. Believing he had an obligation to confront sin he posted biblical citations that were visible to coworkers who complained they were harassed. Peterson agreed to remove the signs but only if the employer would remove its posters supporting its policies of inclusion and equal treatment of gay employees. The employer refused to remove its posters and said Peterson was terminated, not for his religious views but for insubordination because he generated a hostile work environment by his refusal to remove the visible signs.

The trial court agreed with the employer and it's ruling was upheld by the Ninth Circuit Court on appeal, holding that Title VII's duty to accommodate the religious views of an employee (1) does not extend to an employee's desire to impose religious views on coworkers, (2) cannot result in discrimination against coworkers or deprive them of their own contractual or statutory rights, and (3) constitutes an undue hardship on the employer when it attempts to force the employer to exclude sexual orientation from its diversity program established to encourage diversity, inclusion, tolerance, and good will among its workforce, all furthering the employers ability to attract and retain its workforce and succeed in the marketplace. The third principle in the Peterson case, that it would be an undue hardship on the employer to be required to violate anti-discrimination polices is made that much stronger by the Bostock decision.

\section{Interactive Process Required}

Still, when a religious accommodation request is made, the employer should explore possible accommodation and evaluate undue hardship in an attempt to arrive at an accommodation before the request is denied. For example, in Buonanno v AT\&T Broadband LLV (2004), the Eight Circuit upheld a judgment in favor of the employee discharged for refusing on religious ground to sign a document certifying agreement with employer's diversity policy. The evidence showed that the employer didn't even discuss the employee's specific objection or possible accommodation by a slight change to the diversity policy to be signed, before termination.

More recently in Breenan v Deluxe Corp. (2019), the District Court in Maryland held that an issue was presented for trial on behalf of an employee suing for religious discrimination and alleging the employer's failure to undertake the interactive process when his pay was docked and he was ultimately terminated for 
refusing to answer questions about transgender coworkers on employer's ethics course. The court held this was so even though employer's compliance and training provide a nondiscriminatory reason for its action and employees avoidance of that could impose an undue hardship arising from legal exposure to employer.

Not every religious based objection to employer's support for LGBTQ rights will deserve accommodation, but they should be addressed when raised. In Tolle $v$ Rockwell Collins Controls Technologies Inc. (2020), an employee sued for religious harassment and a failure to accommodate his demand that the employer stop its practice of displaying a rainbow Gay Pride flag at its business locations for a 30-day period each year. Several meetings where held with the employers' HR department explaining the employer's intent to support the LGBTQ community and not to discriminate against any particular religion. The court dismissed the case citing Peterson $v$ Hewlett-Packard:

Rockwell Collins's decision to fly the Gay Pride flag during the month of June is similarly consistent with the goals and objectives of our civil rights statutes. When plaintiff challenged that decision, Rockwell Collins, like the employer in Peterson, simply explained the company's diversity initiative and "expressed the expectation that [p]laintiff, like every other employee, come to work each day and treat co-workers in a nondiscriminatory manner.". Rockwell Collins did not ask plaintiff to endorse homosexuality or to abandon his religious beliefs, and explicitly confirmed that it did not support one viewpoint over another and that all employees were entitled to their own beliefs" (Tolle, p.8)

These decisions brought under Title VII show the courts have found that employers support for equal LGBTQ rights are not acts of unlawful religious discrimination nor harassment. Still, employers should take care to at least discuss the matter in the attempt at accommodation, when employees have a religious based conflict with its LGBTQ equal employment policies.

But might an employee with a religious objection have standing to sue under RFRA? Has a court allowed an employee suit against a private sector employer under the RFRA alleging employer's LGBTQ equal employment policy burdens employee's religious liberties? Would the statute's higher accommodation standard of "least restrictive means" be available to defeat that policy? So far no case supports such suit nor the elevated standard for accommodation. The RFRA was passed to protect First Amendment religious rights from direct government action that burdens them. Private employers are not the government and their use of faith neutral nondiscrimination employment policies is not religious discrimination, but instead furthers the government's compelling interest in equal employment rights for all employees. Employees of private sector employers with religious liberty objections to LGBTQ inclusive policies are protected by the mandates of Title VII- freedom from discrimination based on religion, and accommodation, but only to the de minimis standard, if and when a conflict arises. (Brown \& Scott, 2019)

\section{POLICIES RECOMMENDATIONS}

The following recommendations should be considered with advice of retained legal counsel:

Fully recognize equal LGBTQ employment rights. As the Supreme Court has said in the Bostock decision, Title VII requires full recognition and enforcement of equal employment rights for LGBTQ employees. In doing so employers should amend all employment policies, adopt diversity, equality and inclusion training, and enforce equal employment opportunities.

Accommodate transgender employees. Accommodations are required by EEOC decisions and other federal and state authorities. Policies and procedures to do so should be adopted, as the majority of firms in the Fortune 500 have done voluntarily. These include consultation, special medical leave, and insurance benefits, and dress code variances for transgender employees.

Consider the downside risks of firm wide religious based discrimination. Two legal grounds allowing discrimination reserved to religious organizations and affiliates have no application beyond them. Reliance on the RFRA, and the Burwell v Hobby Lobby decision to justify a violation of Title VII prohibited 
workplace discrimination have not been upheld in the courts and is contrary to the existing EEOC position. Aside from legal exposure, employers should also understand LGBTQ employment discrimination is disfavored by most Americans.

Make an honest attempt to accommodate employees' religious views. Title VII prohibits religious discrimination in employment and requires attempts to accommodate employees' religious views. Employers on notice of a request for a religious accommodation should enter into an interactive process, discuss possible accommodations, and conduct an undue hardship evaluation. Undue hardship means de minimis cost or inconvenience. Focus of accommodation should be on flexibility and tolerance toward employee's religious views, rather than accommodating employee conduct that is contrary and harmful to the equal employment rights of others.

Do not accommodate harassment nor insubordination. Employees' conduct, motivated for whatever reason, that causes harassment of others in the workplace, will harm both the firm and its employees. As Peterson demonstrates, an employer does not have to make an accommodation nor tolerate harassment of others because that would cause an undue hardship on the employer through liability exposure, disrupted operations, and a compromised employee equal employment rights. While employers may not be able to eliminate employee religious bias against LGBTQ employees, employers can still require all employees to subordinate that bias and conduct themselves within equal employment policy constraints.

\section{CONCLUDING REMARKS AND CONSIDERATIONS}

Now that LGBTQ employees have been added to those protected by The Civil Rights Act of 1964, some have concerns their addition may burden religious liberties. Firm owner's religious based objections to LGBTQ employment rights rest on narrow grounds. Where employee religious beliefs and practices conflict with employment rules, employers generally have a duty to consider reasonable accommodations, but not at the expense of equal employment rights of others. Employers will need to stay vigilant for conflicts based on religious views of employees as they arise, and use good judgement in deciding whether and to what degree to accommodate them, while protecting equal opportunity. The goal should be to establish a culture of respect and tolerance within, to make that part of their brand outside. Employers will find their employees, clients, customers, and their public stakeholders already expect nothing less.

\section{REFERENCES}

Bostock v Clayton County Georgia, 590 U.S., 140 S. Ct. 1731, WL 3146686. (2020).

Brennan v Deluxe Corp. 361 F. Supp. $3^{\text {rd }}$ 494. (D. Md. 2019).

Brown, E., \& Scott, I. (2019). Belief v. Belief: Resolving Rights Conflicts in the Religious Workplace. $A M B L J, 56,55-113$.

Buonanno v A T\&T, L.L.C. 313 F, Supp. 2d 494. (D. Colo., 2004).

Burwell v Hobby Lobby Stores, Inc. 573 U.S. 682 (2014).

Civil Rights Act of 1964, 42 U.S.C. Sec 2000e et sec.

Civil Rights Act of 1964, 42 U.S.C. Sec. 2000e-1(a).

Ecker, L. (2018). Discrimination in Employment Issues for LGBTQ Individuals. American Bar Association.

EEOC v R.G.\&G.R. Harris Funeral Homes, Inc. 884 F3d 560. (6 $6^{\text {th }}$ Cir 2018).

Employment Division, Department of Human Resources of Oregon v Smith 494 U.S. 872, 110 S. Ct. 1595. (1990).

Equal Emp. Opportunity Comm'n. (n.d.). Fact Sheet: Bathroom Access Rights for Transgender Employees under Title VII of the Civil Rights Act of 1964.

Equal Emp. Opportunity Comm'n. (2014). What you Should Know: Workplace Religious Accommodations. Retrieved from https://www.eeoc.gov/laws/guidance/what-you-should-knowworkplace-religious-accommodation

Equality Act, H.R. 5, S. 788, $116^{\text {th }}$ Congress. (2019-2020) 
Fulton v City of Philadelphia, Pa. (2020). Docket No. 19-123.

Griffin, L.C. (n.d.). The Ministerial Exception Allows Racial Discrimination by Religions. Verdict. Retrieved from https://verdict.justia.com/2020/07/16/the-ministerial-exception-allows-racialdiscrimination-by-religions

Grimm v Gloucester County School Bd. 972 F3rd. 586, 2020 WL 5034430. (4 ${ }^{\text {th }}$ Cir. 2020).

Hosanna-Tabor Evangelical Lutheran Church and School v EEOC, 565 U.S. 171. (2012).

Human Rights Campaign. (n.d.). Corporate Equality Index, 2020. Retrieved from https://www.hrc.org/resources/corporate-equality-index

Kasai, N. (2020). Protecting LGBTQ Employees and Religious Liberty. Third Way. Retrieved from https://www.thirdway.org/memo/protecting-lgbt-employees-and-religious-liberty

Little Sisters of the Poor v Pennsylvania 591 U.S._, 140 S. Ct. 2367. (2020).

Masterpiece Cakeshop v Colorado Civil Rights Commission, 584 U.S._, 138 S. Ct. 1719, WL 2465172. (2018).

Mulvaney, E. (n.d.). LGBT Rights Again on Collision Course at High Court. Bloomberglaw.com.

Retrieved from https://news.bloomberglaw.com/daily-labor-report/religion-lgbt-rights-again-oncollision-course-at-high-court

Obergefell v Hodges 576 U.S. 644. (2015).

Occupational Safety and Health Admin. (n.d.). Best Practices: A Guide to Restroom Access for Transgender Workers. Retrieved from https://www.osha.gov/Publications/OSHA3795.pdf

Off. of Personnel Mgmt. (n.d.). Guidance Regarding the Employment of Transgender Individuals in the Federal Workplace.

Peterson v Hewlett-Packard Co. 358 F3rd 599 (9th Cir. 2004).

Religious Freedom Restoration Act of 1993, 107 Stat. 1488, 42 U.S. Sec. 2000 bb et. seq.

R.G. \& G.R. Harris Funeral Homes, Inc. v E.E.O.C. 590 U.S., 140 S. Ct. 1731, WL 3146686. (2020).

Simmons-Duffin, S. (2020). Whiplash of LGBTQ Protections and Rights, From Obama to Trump.

National Public Radio. Retrieved from https://www.wbur.org/npr/804873211/whiplash-of-lgbtqprotections-and-rights-from-obama-to-trump

Tolle v Rockwell Collins Control Technologies, Inc. 2020 WL 3316984. (D. Va. 2020).

Trans World Airlines, Inc. v Hardison 432 U.S. 63. (1977).

Zarda v Altitude Express 590 U.S. _, 140 S. Ct. 1731, WL 3146686. (2020). 